\title{
Infection of 'd'Anjou' Pear Fruit by Potebniamyces pyri in the Orchard in Relation to Phacidiopycnis Rot during Storage
}

\author{
Q. Liu and C. L. Xiao, Department of Plant Pathology, Washington State University, Tree Fruit Research and Exten- \\ sion Center, Wenatchee 98801
}

\begin{abstract}
Liu, Q., and Xiao, C. L. 2009. Infection of 'd'Anjou' pear fruit by Potebniamyces pyri in the orchard in relation to Phacidiopycnis rot during storage. Plant Dis. 93:1059-1064.

Phacidiopycnis rot, caused by Potebniamyces pyri, is a recently recognized postharvest fruit rot disease of 'd'Anjou' pear (Pyrus communis) in the United States. To determine the timing of fruit infection in the orchard in relation to incidence of Phacidiopycnis rot during storage, fruit were inoculated in the orchard at different times during the growing season, harvested, and monitored for decay development during storage at $0^{\circ} \mathrm{C}$. Fruit inoculated in the field and laboratory were also used to determine the infection courts and the importance of necrotic tissues to infection of sepals that may lead to calyx-end Phacidiopycnis rot. Phacidiopycnis rot was observed during cold storage on the fruit inoculated any time after bloom till near harvest but not on the fruit inoculated during bloom. Phacidiopycnis rot symptoms only developed at the stem and calyx end of the fruit during storage. Relatively more calyx-end rot was observed than stemend rot on the fruit inoculated before August. Incidence of stem-end rot increased significantly on the fruit inoculated near harvest. Incidence of total Phacidiopycnis rot increased as the timing of fruit infection in the orchard approached harvest. Potebniamyces pyri was recovered more frequently from sepals than from styles and stamens of the fruit. Most infections on sepals were associated with the necrotic tissues. Naturally occurring necrotic tissues occurred on more than $85 \%$ and all sepals in the early fruit-growing and late growing seasons, respectively. Such necrotic tissues on sepals could serve as potential infection sites for $P$. pyri. The results may suggest that chemical control of Phacidiopycnis rot should focus on protecting the pedicel (stem) and floral parts of fruit and that fungicides applied near harvest are likely most important in controlling latent infections of pear fruit by P. pyri leading to Phacidiopycnis rot during storage.
\end{abstract}

Winter pear fruit (Pyrus communis L.) in the United States are produced primarily in the Pacific Northwest (PNW). 'd'Anjou' is a dominant cultivar of winter pear and is mainly produced in the Wenatchee River Valley in Washington State and the Hood River Valley in Oregon (8). In the Wenatchee River Valley, d'Anjou pear fruit are harvested in mid-September and are initially stored in the field-bins in cold storage. Packing starts shortly after harvest and may not be finished until early December. During packing, visually sound fruit are individually wrapped in paper impregnated with copper sulfate, which is used to prevent fruit-to-fruit spread of decay, and packed in cardboard boxes lined with perforated polyethylene bags (7). Packed fruit may be stored for up to 9

Corresponding author: C. L. Xiao

E-mail: clxiao@wsu.edu

This manuscript is Plant Pathology New Series 0454, Department of Plant Pathology, College of Agricultural, Human, and Natural Resources Sciences Agricultural Research Center, Project No. WNP00367, Washington State University, Pullman, WA 99164-6430.

Accepted for publication 1 July 2009.

doi:10.1094/PDIS-93-10-1059

(C) 2009 The American Phytopathological Society months in controlled atmosphere (1 to $2 \%$ oxygen and $0.5 \%$ carbon dioxide) at -1 to $0^{\circ} \mathrm{C}(15)$. Fruit decay resulting from various postharvest diseases that develop in packed pear fruit stored in cardboard boxes is considered one of the most serious problems to pear packers in the PNW (7). Repacking is required before fruit are shipped to markets if the incidence of decay in pear boxes exceeds the $2 \%$ limit in Washington State. Millions of dollars may be lost annually because of direct losses due to fruit decay and indirect costs associated with repacking, and control of postharvest diseases is critical to the profitability of d'Anjou pear production in the region (7).

Phacidiopycnis rot, caused by Potebniamyces pyri (Berk. \& Broome) Dennis (anamorph Phacidiopycnis piri (Fuckel) Weindlm.), is a recently recognized postharvest fruit-rot disease of winter pear in the United States (29). Stem-end rot and calyx-end rot are the two major types of symptoms of Phacidiopycnis rot in d'Anjou pear fruit (29). In Washington State, Phacidiopycnis rot is one of the major postharvest diseases in packed d'Anjou pear fruit (29). Phacidiopycnis rot has previously been recorded on pome fruit in Europe and India $(23,26)$ but little information is available about the epidemiology of Phacidiopycnis rot in these production regions.
Potebniamyces pyri is a caulicolus discomycete (4). The fungus is widespread in major d'Anjou pear-production areas in the PNW and is commonly associated with cankers, twig dieback, and dead bark of pear trees (30). Pycnidia of $P$. pyri are commonly present on dead bark and cankers on the trees. Apothecia may also be present on infected trees but at a very low frequency. Viable pycnidia are present throughout the pear-growing season, and conidia are believed to be the primary inoculum responsible for infection of fruit in pear orchards (30). Both conidia and ascospores of $P$. pyri are waterborne (4). Conidia and ascospores germinate by budding and producing germ tubes $(10,20)$. Conidia germinate at 0 to $30^{\circ} \mathrm{C}$, with an optimum temperature of approximately $20^{\circ} \mathrm{C}(10)$. A minimum of 4 to $5 \mathrm{~h}$ is required for conidia to germinate by budding and $8 \mathrm{~h}$ to produce germ tubes at the optimum temperatures (10). The effects of temperature on mycelial growth are similar to those on conidial germination (31). The mode of conidial germination was influenced by nutrient level and moisture (10). Because decay symptoms are absent at harvest, it is believed that $P$. pyri infects pear fruit in the orchard, remains latent, and then develops into stem-end rot and calyx-end rot during storage (29). However, it is not known when infection of the pedicel and floral parts of the fruit by $P$. pyri occurs in the orchard and how infection of fruit at different times during the fruit-growing season contributes to incidence of Phacidiopycnis rot in storage.

Postharvest fruit rots resulting from quiescent or incipient infections of floral parts of the fruit by pathogens occur on many fruit crops, and pathogens may use various pathways for floral infections leading to postharvest fruit rots. Botrytis cinerea causes fruit infections through filaments of flowers in pear (3) and strawberry $(2,21)$, through styles at bloom in black currant (13) and red raspberry (14), and through sepals in strawberry $(2,21)$ and kiwifruit $(16,17)$. Monilinia laxa causes fruit decay in plum through infecting filaments and sepals of blossoms (22), while M. vacciniicorymbosi infects blueberry fruit through styles at bloom $(18,24)$. It is not known what floral parts of pear fruit through which $P$. pyri infects the fruit leading to calyx-end Phacidiopycnis rot.

Various factors, including fruit maturity and susceptibility $(6,12,17)$ and environ- 
mental factors, affect the incidence of fungal infections that lead to postharvest fruit rots $(1,11,19)$. In addition, availability of susceptible fruit tissues is also important for the pathogens to colonize the fruit. In strawberry, the majority of infections on sepals by $B$. cinerea were found associated with necrotic tissues (21). P. pyri is a weak canker-causing pathogen on pear trees. When inoculating pear twigs in the orchard, the presence of dead tissues on twigs is critical to the successful colonization of the twigs by P. pyri (30). However, it is not clear whether the necrotic tissues of floral parts are also important to the floral infection by $P$. pyri.

The objectives of this study were to determine (i) timing of pear fruit infection by $P$. pyri in the field in relation to development of Phacidiopycnis rot during storage, (ii) floral infection courts of d'Anjou pear fruit by $P$. pyri, and (iii) importance of naturally occurring necrotic tissues in infection of sepals by $P$. pyri that may lead to calyx-end Phacidiopycnis rot.

\section{MATERIALS AND METHODS}

Preparation of inoculum. $P$. pyri isolate CLX210 was used throughout this study. Mature pycnidia, 10 to 12 weeks old, that were produced according to the protocol of Xiao and Sitton (31) were removed from the medium surface with a scalpel and ground with a pestle in a mortar to release conidia. Sterile water was added to the mortar to make a conidial suspension and conidia were filtered through four layers of cheesecloth. The concentration of the conidial suspension was adjusted to $1 \times 10^{5}$ conidia/ml with a hemacytometer. Tween 20 was added to a final concentration of $0.001 \%$.

Timing of infection of pear fruit in the orchard in relation to Phacidiopycnis rot in storage. Fruit inoculations were conducted in 2003 and 2004 in a research orchard of d'Anjou pear located near Orondo, WA. Trees were under-tree irrigated. Insects and weeds were controlled following the recommendations commonly used for commercial pear production (25). No fungicides were used in this orchard during the course of the experiment.

Inoculations were initiated at bloom and continued at approximately 6-week intervals until harvest during each season. The experiment was a randomized complete block design within the field. In 2003, 40 flower clusters or 20 fruit were inoculated for each of four replicate trees per date. Due to a poor fruit set in 2004, 50 fruit were inoculated for each of three replicates at each inoculation time. Flower clusters or pear fruit were inoculated by spraying them with the conidial suspension of $P$. pyri until runoff, and those sprayed with sterile water were used as controls. Inoculated flower clusters or fruit were covered with moistened plastic bags. To prevent high temperatures inside plastic bags caused by sunlight, plastic bags were covered by paper bags. Inoculations were always conducted during late afternoon and bags were removed early the next morning. Wetness duration on the flowers or fruit was approximately $12 \mathrm{~h}$ for all inoculations. A WatchDog data logger (model 450; Spectrum Technologies, Inc., East-Plainfield, IL) was used to record temperature and relative humidity inside the plastic bags during the period of incubation for all inoculations.

Fruit of all treatments were harvested on 11 September 2003 and on 10 September 2004. Fruit were examined for any disease symptoms at the pedicel (stem) and calyx before they were placed on fiberboard fruit trays in cardboard boxes lined with perforated polyethylene bags and stored in air at $0^{\circ} \mathrm{C}$ for 7 months. All fruit were visually examined for decay development (calyxend rot and stem-end rot) every 2 weeks, starting in late December. In cases where decay developed at only one end of the fruit (stem end or calyx end) and the entire fruit could rot before the next rating, reisolation of $P$. pyri from the opposite symptomless pedicel or floral parts of the fruit was attempted to determine whether $P$. pyri was present.

Linear regression analysis was conducted using regression procedures of SAS PROC REG (version 9.1; SAS Institute, Cary, NC) to determine relationships between the incidence of calyx-end rot, stemend rot, or total Phacidiopycnis rot in storage and time of fruit inoculation in the field (number of days from fruit inoculation to pear harvest). The date of pear harvest was assigned as day 0 and, thus, the values of the number of days prior to harvest were negative. A $t$ test using SAS PROC TTEST was performed to determine whether the incidences of calyx-end rot and stem-end rot resulting from each inoculation time were significantly different $(P \leq 0.05)$.

Infection courts on fruit. Fruit inoculated in the field as described above were used for this study. In 2003, 10 fruit inoculated in August were randomly selected and brought back to the laboratory 1 week after inoculation. Styles (including stigmata), stamens (consisting of filaments and anthers), and sepals of each fruit were used in attempts to reisolate $P$. pyri. The floral parts of each fruit were excised and surface sterilized in $0.5 \%$ sodium hypochlorite for $3 \mathrm{~min}$, rinsed with three changes of sterile water, and dried on sterilized paper towels. Styles, stamens, and sepals of each fruit were excised, separated, and plated onto acidified potato dextrose agar (APDA; Difco Laboratories, Detroit; $4 \mathrm{ml}$ of $25 \%$ lactic acid per liter of medium). Plates were incubated at $20^{\circ} \mathrm{C}$ in the dark for 4 days and the frequency of colonization of each type of floral part was recorded. A $\chi^{2}$ test using SAS PROC FREQ was performed to determine whether the difference in frequencies of colonization of $P$. pyri between any two types of floral parts was significant at $P \leq$ 0.05 . The experiment was repeated in 2007 at 1 week before harvest. Three replicate trees, each with 20 fruit, arranged in a complete randomized design were inoculated as described above. Fruit were picked 1 week after inoculation and brought back to the lab. Floral parts of each fruit were subjected to reisolation of $P$. pyri as described above. Analysis of variance was conducted using SAS PROC ANOVA to determine whether the differences in percentages of colonization (the number of colonized tissues/the total number of each floral parts of the fruit) among three floral parts were significant, and means were separated by Fisher's protected least significant difference $(P=0.05)$.

Importance of naturally occurring necrotic tissue in the colonization of sepals by $P$. pyri. Fruit inoculation experiments were conducted in the laboratory. All d'Anjou pear fruit used for laboratory inoculations were picked from a pear orchard in Leavenworth, WA. Pear fruit were surface-sterilized with $70 \%$ ethanol for $1 \mathrm{~min}$, rinsed with three changes of sterile water, and air dried. The calyx of fruit was inoculated by dipping the whole fruit into the conidial suspension of the pathogen for $30 \mathrm{~s}$. Fruit were then placed into muffin trays in a plastic container and covered with a layer of moist paper towel. Each container was enclosed in a moistened plastic bag. After incubation for $24 \mathrm{~h}$ at $20^{\circ} \mathrm{C}$, pear fruit were air dried with a fan for $1 \mathrm{~h}$ and incubated for an additional $48 \mathrm{~h}$ in dry containers at $20^{\circ} \mathrm{C}$. In August 2004, 65 fruit were inoculated and 324 sepals from the inoculated fruit were subjected to isolation of $P$. pyri. Necrotic and apparently healthy tissues of sepals of each fruit were plated separately on the same APDA plate. Frequency of colonization of each type of tissue was recorded and a $\chi^{2}$ test was calculated to determine whether the frequencies of colonization on two types of tissues were significantly different at $P \leq 0.05$ using SAS PROC FREQ.

The experiment also was performed twice in August 2005. Nine fruit per each of three replicates were inoculated. $\mathrm{Ne}$ crotic and apparently healthy tissues of the sepals of each fruit were plated separately onto the same APDA plate as described above. The number of necrotic and healthy tissues of the same sepal colonized by $P$. pyri was recorded to calculate the percentage of colonization of two types of tissues. A Student's $t$ test was conducted using SAS PROC TTEST to determine whether the differences in percentages of colonization between two types of tissues were significant at $P \leq 0.05$.

To determine availability of naturally occurring necrotic tissues on sepals of the fruit in the orchard, 30 pear fruit were 
collected from the same commercial pear orchard approximately every 2 weeks from early June to mid-August in 2005 and 2006. The number of sepals with necrotic tissues and the percent necrotic area on each sepal were estimated using a dissecting microscope. The averages of percent sepals with necrotic tissues and the percent necrotic area on sepals of the 30 fruit were calculated at each sampling time.

\section{RESULTS}

Timing of infection of pear fruit in the orchard in relation to Phacidiopycnis rot during storage. During each fruit inoculation, relative humidity inside the plastic bags was near $100 \%$. Temperatures during the period of incubation of inoculated flowers conducted in early April ranged from 7 to $18^{\circ} \mathrm{C}$. The temperatures during incubation at other inoculation dates ranged from 15 to $25^{\circ} \mathrm{C}$, which are favorable for conidial germination of $P$. pyri. Temperatures above $30^{\circ} \mathrm{C}$ occurred for less than $3 \mathrm{~h}$ in July and August at the beginning of inoculation due to sunlight in the afternoon but likely did not affect conidial germination based on previous in vitro observations (10).

In both years, at harvest, the pedicel of inoculated fruit visually appeared healthy and the calyx-end looked normal (no decay at the calyx end, except visible necrotic tissues on floral parts). Calyx-end and stem-end Phacidiopycnis rot developed during storage in inoculated fruit but not in the noninoculated control fruit. Fruit decay originating from lenticels was not observed during storage. Occasionally, $P$. pyri was reisolated from the stem of a calyx-end-decayed fruit or from the calyx of a stem-end-decayed fruit (data not shown).

No fruit developed decay during storage when they were inoculated at bloom. In general, incidence of calyx-end rot in storage was higher than that of stem-end rot on the fruit inoculated before August in both years (Fig. 1). As the inoculation date approached harvest, incidence of calyx-end rot increased significantly $(y=39.655+$ $\left.0.2683 x, R^{2}=0.7392, P=0.006\right)$. Incidence of stem-end rot in storage was low on the fruit inoculated before August but increased significantly on the fruit inoculated in August (approximately 2 weeks before harvest) in both years $(y=26.404+$ $0.2031 x ; R^{2}=0.6747, P=0.012$ ) (Fig. 1). Total Phacidiopycnis rot in storage increased linearly as the timing of fruit infection in the field approached harvest (Fig. 2).

Infection of floral parts of pear fruit by $\boldsymbol{P}$. pyri. $P$. pyri was reisolated from all three floral parts of the fruit but the frequency of infection by $P$. pyri in sepals was significantly higher than that in styles and stamens (Fig. 3). When the necrotic and apparently healthy tissues of sepals were plated separately, incidence of recov-
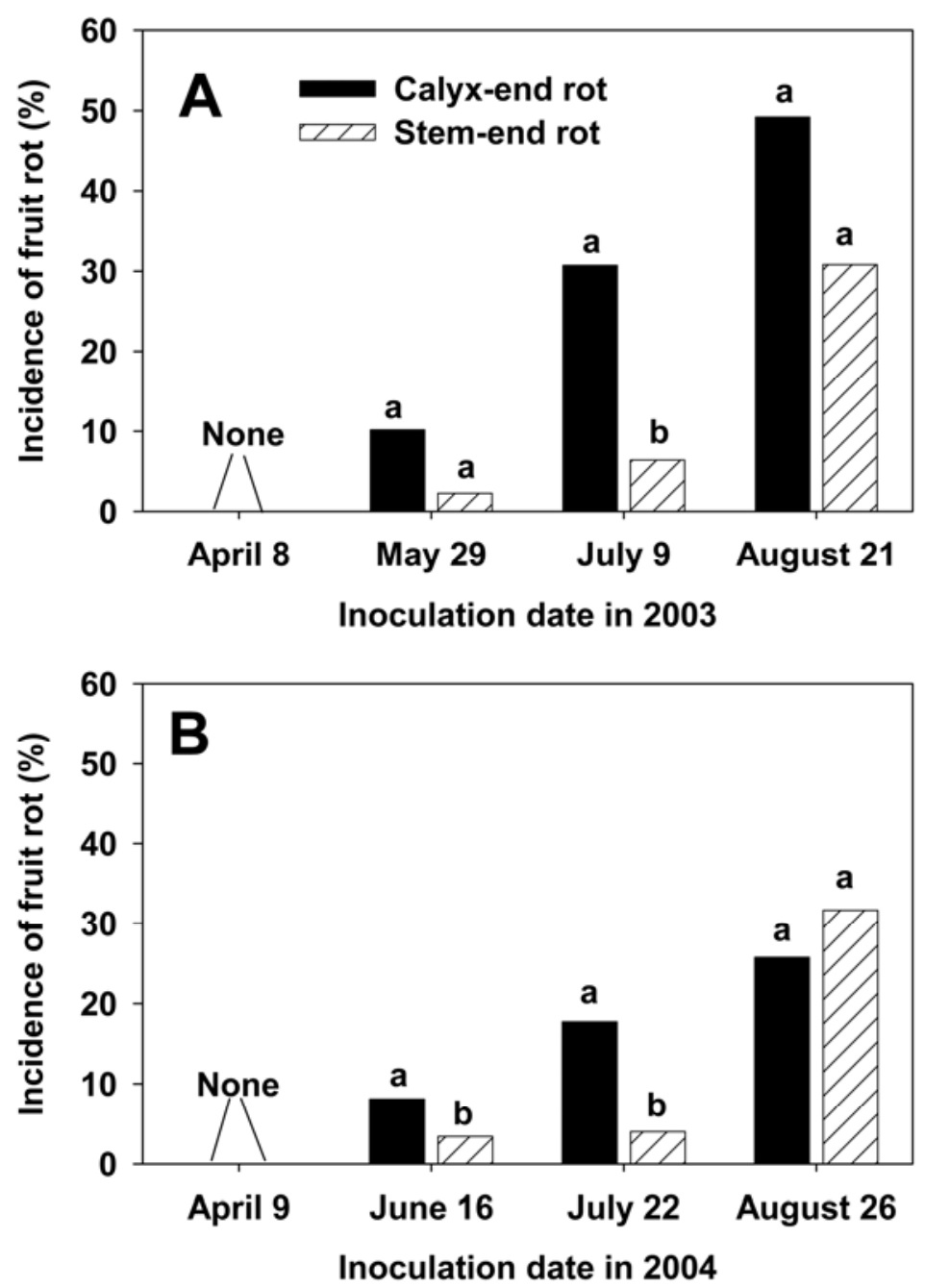

Fig. 1. Incidence of calyx-end Phacidiopycnis rot and stem-end Phacidiopycnis rot 7 months after harvest on fruit inoculated in the orchard at different dates in A, 2003 and B, 2004. Incidence of calyxend rot and stem-end rot at each inoculation date represented the average of four replicates in 2003 and three replicates in 2004. Bars within each inoculation date are marked with different letters if values differ significantly at $P \leq 0.05$ according to the Student's $t$ test.

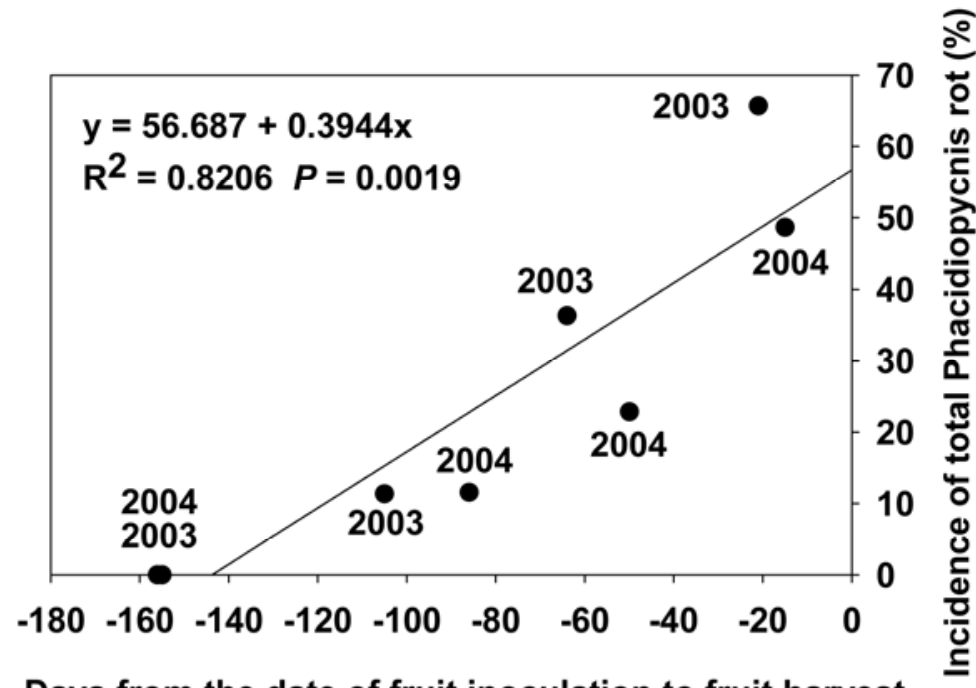

\section{Days from the date of fruit inoculation to fruit harvest}

Fig. 2. Relationship between incidence of total Phacidiopycnis rot in storage and days from the date of each fruit inoculation to the date of pear fruit harvest of each year. After harvest, fruit were stored at $0^{\circ} \mathrm{C}$ for 7 months for monitoring decay development. The numbers of the $\mathrm{X}$-axis were given negative values because the day at the fruit harvest was set to 0 and the inoculations were conducted before fruit harvest. Each dot represents the average of four replicates in 2003 and three replicates in 2004. 
ery of $P$. pyri from necrotic tissues was significantly higher than that of healthy tissues (Fig. 4). P. pyri was reisolated from $63.3,45.2$, and $76.3 \%$ of the necrotic tis- sues on sepals in the three experiments, respectively, whereas only from $10.5,5.9$, and $6.7 \%$ of the apparently healthy tissues (Fig. 4).

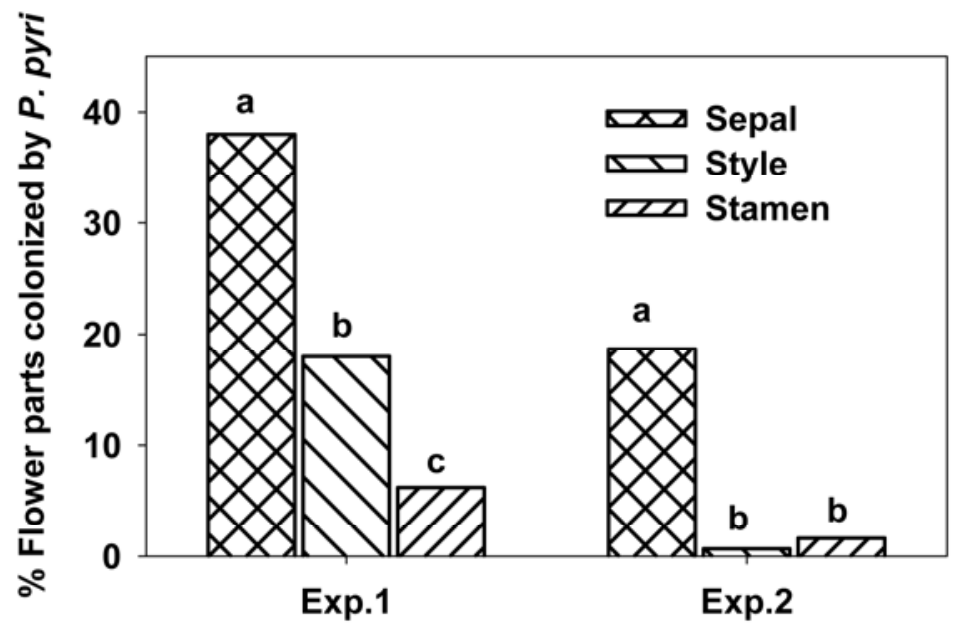

Field fruit inoculations

Fig. 3. Incidence of Potebniamyces pyri infections on sepals, styles, and stamens of d'Anjou pear fruit inoculated in the orchard. Experiment 1 was conducted on 10 fruit in August 2003. Experiment 2 was conducted on three 20-fruit replicates in August 2007. Bars within each experiment are marked with different letters if values differ significantly at $P \leq 0.05$ according to the $\chi^{2}$ test (experiment 1 ) or Fisher's protected least significant difference (experiment 2 ).
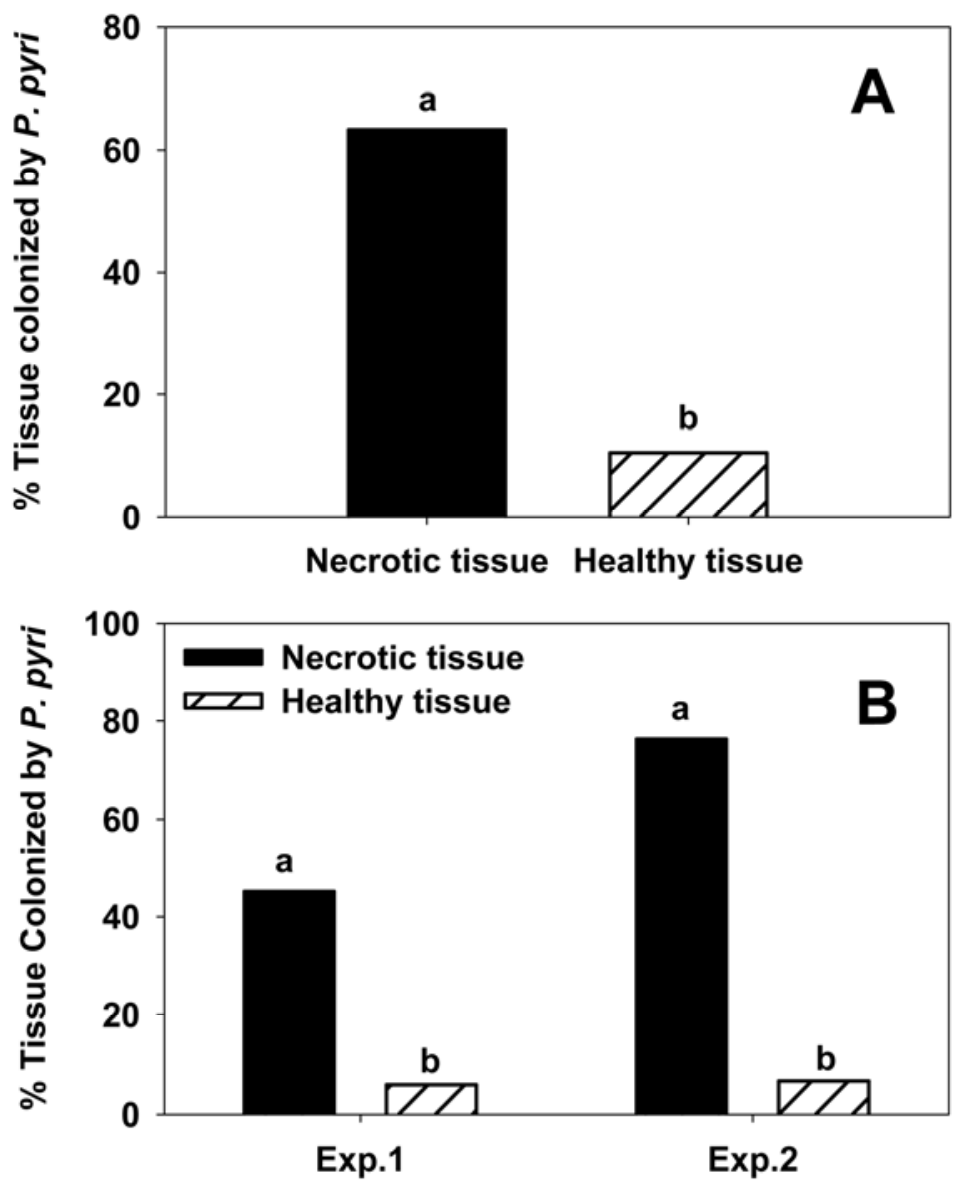

Fig. 4. Colonization of necrotic and apparently healthy sepal tissues of d'Anjou pear fruit inoculated in the laboratory. A, Result based on 324 sepals of 65 fruit inoculated in August 2004. Bars are marked with different letters if values differ significantly at $P \leq 0.05$ according to the $\chi^{2}$ test. B, Result of fruit inoculated in August 2005. Each bar represents the average of three nine-fruit replicates. Bars within each experiment marked with different letters differ significantly at $P \leq 0.05$ according to the Student's $t$ test.

Availability of naturally occurring necrotic tissues on the sepals of pear fruit. Necrotic tissues on sepals were commonly observed on healthy pear fruit in the orchard. The necrotic tissues started at the tip of the sepal. In both years, more than $85 \%$ of the sepals already had necrotic tissues in June (the early fruit-growing season) (data not shown). The percentage of sepals with necrotic tissues increased as the season progressed and all the sepals had necrotic tissues by August (mid- to late fruitgrowing season). The average necrotic area was less than $5 \%$ of the whole sepal in the early season but it increased gradually as the season progressed, reaching 15 to $20 \%$ of the whole sepal in the late season (data not shown).

\section{DISCUSSION}

In this study, we documented that infection of pear fruit by $P$. pyri could occur in the field as early as after bloom until harvest but infections remained latent and stem-end and calyx-end Phacidiopycnis rot symptoms developed only during storage. We found that incidence of calyx-end Phacidiopycnis rot in storage increased as the timing of fruit infection in the orchard approached harvest. Increased incidence of calyx-end Phacidiopycnis rot was likely related to increased incidence and severity of naturally occurring necrotic tissues on sepals as the growing season progressed because $P$. pyri can easily establish infections on the necrotic tissues (30). Incidence of stem-end Phacidiopycnis rot increased significantly only when fruit were inoculated in late August, approximately 2 weeks before harvest. It is possible that susceptibility of the fruit pedicel to infection by $P$. pyri increased significantly only when fruit were nearing maturity. Similarly, increase in fruit susceptibility has been found in prune fruit approaching harvest to infection by $M$. fructicola (12) and in d'Anjou pear fruit to infection by $B$. cinerea in the last month before harvest (27).

Furthermore, we found that the amount of Phacidiopycnis rot developed during storage differed significantly when fruit were infected at different times during the fruit-growing season. The results indicated that infections of fruit near harvest contributed most to the total amount of Phacidiopycnis rot, including both stem-end rot and calyx-end rot, in storage. Similar results were also found in calyx-end gray mold on d'Anjou pear fruit when fruit were inoculated with $B$. cinerea in the field at different dates in the orchards (9).

In our study, we observed that infection by $P$. pyri was initiated only at the pedicel (stem) and floral parts of the fruit. Infection of lenticels on fruit skin was not observed. The results indicated that $P$. pyri is different from Neofabraea spp., which colonize lenticels of pear fruit skin and remain latent in the field but, in storage, 
lead to bull's eye rot, another common postharvest disease of pear in the region (28). The results also suggest that chemical control of Phacidiopycnis rot should focus on protecting the pedicel and floral parts of fruit and that fungicides applied near harvest are likely most important in controlling latent infections leading to Phacidiopycnis rot in storage.

P. pyri was able to colonize sepals, styles, and stamens of the fruit but colonization occurred more frequently on sepals than on styles and stamens. Previous studies have shown that calyx-end rot in different fruit-pathogen pathosystems may originate from infections at different floral parts of fruit $(2,3,13,14,17,18,21,22,24)$. Furthermore, we found that infections on sepals by $P$. pyri were mainly associated with naturally occurring necrotic tissues. This is consistent with observations by Xiao and Boal (30) that P. pyri is a weak pathogen on pear trees and establishes readily in dead tissues. Powelson (21) observed similar results in strawberry fruit rot caused by $B$. cinerea, in which most infections on sepals are associated with necrotic tissues. In pear fruit, however, de Kock and Holz (3) found that fungal structures of $B$. cinerea in sepals are not the result of direct penetration but, instead, from systemic growth originating from infected filaments. Occurrence of necrotic tissues on sepals of d'Anjou pear fruit is a natural phenomenon, and most of the necrotic tissues are associated with the tips of sepals. In this study, we further documented that such necrotic tissues already occurred on the majority of sepals in the early growing season and could serve as potential infection sites for $P$. pyri.

In our study, flowers inoculated with $P$. pyri during bloom did not result in calyxend Phacidiopycnis rot in storage, indicating that conidial dissemination during the bloom period was not critical to infection of the fruit by P. pyri. Similar results were found by Fourie and $\mathrm{Holz}$ (5), in which flower infections by $B$. cinerea are of little importance to postharvest decay in plum and nectarine. However, we observed that calyx-end Phacidiopycnis rot developed on the fruit inoculated at all other inoculation dates after bloom. Previous studies on $B$. cinerea showed that not all infected floral parts lead to fruit decay in other fruit crops such as pear (3) and strawberry (2). In our study, although $P$. pyri was isolated more frequently from sepals than from styles and stamens of the fruit, the importance of styles and stamens as potential infection courts leading to Phacidiopycnis rot cannot be ruled out because we were able to recover the fungus from these tissues. A higher frequency of recovery of $P$. pyri from sepals may be because there are more sepal tissues than style and stamen tissues available for infection. More work, including microscopy, is still needed to clarify the exact contributions of infection of each floral part to the development of calyx-end Phacidiopycnis rot and determine the locations where quiescent fungal structures of $P$. pyri reside after successful penetration of floral tissues.

Various factors may affect relationships between preharvest infections of pear fruit at different periods during the growing season and incidence of Phacidiopycnis rot in storage. No Phacidiopycnis rot in storage was observed on the fruit inoculated at bloom. Based on the weather data recorded during incubation periods after inoculation, low evening temperatures were encountered at inoculations during bloom in both years. The low temperatures recorded ( 7 to $18^{\circ} \mathrm{C}$ ) likely delayed conidial germination (10) and, thus, infection of fruit was unsuccessful. For inoculations on other dates, however, temperatures during incubation periods after inoculation were within ranges suitable for conidial germination and subsequent host penetration from mycelial growth (10,31). Survival of $P$. pyri in infected fruit during the growing season might also affect incidence of Phacidiopycnis rot in storage. Temperatures in July and August in the area are usually high, with maximum temperatures at the experiment site reaching 41 and $38^{\circ} \mathrm{C}$ in July and August, respectively, in 2003, and $41^{\circ} \mathrm{C}$ in both months in 2004 . A previous study indicated that $P$. pyri can survive as mycelium in diseased twigs in the orchard throughout the year in the area of Wenatchee, WA (30). It is likely that $P$. pyri in infected pear fruit also survived during the fruit-growing season; however, survival of conidia and mycelia of $P$. pyri could be affected after they were exposed to such high temperatures for a prolonged period (30). Thus, a further study to determine survival of $P$. pyri on the fruit surface and in infected fruit in response to environmental conditions would help us refine relationships between timing of fruit infection in the field and development of Phacidiopycnis rot in storage.

In summary, in this study we found that sepals were the primary floral infection sites on pear fruit by $P$. pyri and that infections of pear fruit near the time of harvest were most important to development of Phacidiopycnis rot in storage. Because Phacidiopycnis rot develops only in storage, future research could focus on development of a rapid and reliable assay for early detection of pear fruit infection by $P$. pyri. An early detection of pear infection by $P$. pyri near harvest would help growers and packers assess the risk of Phacidiopycnis rot in storage and enable implementation of relevant measures for disease control prior to harvest or storage of fruit.

\section{ACKNOWLEDGMENTS}

This research was supported in part by the Washington State University Agricultural Research Center Graduate Research Assistant Enhancement Program, the Fresh Pear Committee, and the Wash- ington Tree Fruit Research Commission. We thank R. J. Boal, C. Kahn, Y. K. Kim, and H. Li for assistance with fruit inoculation in the field; and M. Mazzola, T. L. Peever, and J. D. Rogers for critical review of an earlier version of the manuscript.

\section{LITERATURE CITED}

1. Adam, D. B., McNeil, J., Hanson-Merz, B. M., McCarthy, D. F., and Stokes, J. 1949. The estimation of latent infection in oranges. Aust. J. Sci. Res. Ser. B 2:1-18.

2. Bristow, P. R., McNicol, R. J., and Williamson, B. 1986. Infection of strawberry by Botrytis cinerea and its relevance to grey mold development. Ann. Appl. Biol. 109:545-554.

3. de Kock, S. L., and Holz, G. 1992. Blossomend rot of pears: systemic infection of flowers and immature fruit by Botrytis cinerea. J. Phytopathol. 135:317-327.

4. DiCosmo, F., Nag Raj, T. R., and Kendrick, W. B. 1984. A revision of the Phacidiaceae and related anamorphs. Mycotaxon 21:1-234.

5. Fourie, J. F., and Holz, G. 1994. Infection of plum and nectarine flowers by Botrytis cinerea. Plant Pathol. 43:309-315.

6. Fourie, J. F., and Holz, G. 1995. Initial infection process by Botrytis cinerea on nectarine and plum fruit and the development of decay. Phytopathology 85:82-87.

7. Kupferman, E. A. 1995. Practices to reduce postharvest pear diseases. Tree Fruit Postharvest J. 6:18-23.

8. Kupferman, E. A. 1998. Postharvest applied chemicals to pears: a survey of pear packers in Washington, Oregon, and California. Tree Fruit Postharvest J. 9:3-24.

9. Lennox, C. L., and Spotts, R. A. 2004. Timing of preharvest infection of pear fruit by Botrytis cinerea and the relationship to postharvest decay. Plant Dis. 88:468-473.

10. Liu, Q., and Xiao, C. L. 2005. Influence of nutrient and environmental factors on conidial germination of Potebniamyces pyri. Phytopathology 95:572-580.

11. Luo, Y., Ma, Z. H., and Michailides, T. J. 2001. Analysis of factors affecting latent infection and sporulation of Monilinia fructicola on prune fruit. Plant Dis. 85:999-1003.

12. Luo, Y., and Michailides, T. J. 2001. Factors affecting latent infection of prune fruit by Monilinia fructicola. Phytopathology 91:864-872.

13. McNicol, R. J., and Williamson, B. 1989. Systemic infection of black currant flowers by Botrytis cinerea and its possible involvement in premature abscission of fruits. Ann. Appl. Biol. 114:243-254.

14. McNicol, R. J., Williamson, B., and Dolan, A 1985. Infection of red raspberry styles and carpels by Botrytis cinerea and its possible role in post-harvest grey mold. Ann. Appl. Biol. 106:49-53.

15. Meheriuk, M. 1993. CA storage conditions for apples, pears, and nashi. Pages 819-841 in: Proc. 6th Int. Controlled Atmosphere Res. Conf. Cornell University, Ithaca, NY.

16. Michailides, T. J., and Elmer, P. A. G. 2000. Botrytis gray mold of kiwifruit caused by $\mathrm{Bo}$ trytis cinerea in the United States and New Zealand. Plant Dis. 84:208-223.

17. Michailides, T. J., and Morgan, D. P. 1996. Using incidence of Botrytis cinerea in kiwifruit sepals and receptacles to predict gray mold decay in storage. Plant Dis. 80:248-254.

18. Ngugi, K. H., Scherm, H., and Lehman, J. S. 2002. Relationship between blueberry flower age, pollination, and conidial infection by Monilinia vaccinii-corymbosi. Phytopathology 92:1104-1109.

19. Peterson, R. A. 1978. Susceptibility of Fuerte avocado fruit at various stages of growth, to infection by anthracnose and stem end rot fungi. Aust. J. Exp. Agric. Anim. Husb. 18:158-160.

20. Potebnia, A. 1912. Ein neuer Krebserreger des Apfelbaumes Phacidiella discolor (Mout. Et 
Sacc.) A. Pot., seine Morphologie und Entwickelungs-geschichte. Z. Pflanzenkrankh. 22:129-153.

21. Powelson, R. L. 1960. Initiation of strawberry fruit rot caused by Botrytis cinerea. Phytopathology 50:491-494.

22. Schlagbauer, H. E., and Holz, G. 1990. Infection and colonization of plum blossom by Monilinia laxa. Phytophylactica 22:419-422.

23. Sharma, R. L. 1991. Prevalence of storage rots of China pear in Himachal Pradesh. Plant Dis. Res. 5:109-111.

24. Shinners, T. C., and Olson, A. R. 1996. The gynoecial infection pathway of Monilinia vaccinii-corymbosi in lowbush blueberry (Vaccinium angustifolium). Can. J. Plant
Sci. 76:493-497.

25. Smith, T. J., Dunley, J., Beers, E. H., Brunner, J. F., Grove, G. G., Xiao, C. L., Elfving, D. C., Peryea, F., Parker, R., Mayer, D. F., Woodruff, R., Daniels, C., Maxwell, T., and Roberts, S. 2004. 2004. Crop Protection Guide for Tree Fruits in Washington. Washington State University Extension Bulletin (EB 0419).

26. Snowdon, A. L. 1992. Post-Harvest Disease and Disorders of Fruits and Vegetables. Vol. 1. General Introduction and Fruits. CRC Press, Boca Raton, FL.

27. Spotts, R. A. 1985. Effect of preharvest pear maturity on decay resistance. Plant Dis. 69:388-390.

28. Spotts, R. A. 1990. Bull's-eye rot. Page 56 in:
Compendium of Apple and Pear Diseases. A. L. Jones and H. S. Aldwinckle, eds. American Phytopathological Society, St. Paul, MN.

29. Xiao, C. L., and Boal, R. J. 2004. Prevalence and incidence of Phacidiopycnis rot in d'Anjou pears in Washington State. Plant Dis. 88:413-418.

30. Xiao, C. L., and Boal, R. J. 2005. Distribution of Potebniamyces pyri in the U.S. Pacific Northwest and its association with a canker and twig dieback disease of pear trees. Plant Dis. 89:920-925.

31. Xiao, C. L., and Sitton, J. W. 2004. Effects of culture media and environmental factors on mycelial growth and pycnidial production of Potebniamyces pyri. Mycol. Res. 108:926-932. 